\title{
TWO DIFFERENT BREEDER AGES AND TWO PERIODS OF POST-HATCHING FASTING ON IMMUNITY OF BROILERS
}

\section{Duas idades distintas de matrizes e dois períodos de jejum pós-eclosão sobre a imunidade de frangos de corte}

\author{
VARGAS, F.S.C. ${ }^{1}$; BARATTO, T. ${ }^{1}$; BONA, T.D.M.M. ${ }^{2}$; MAIORKA, A. ${ }^{2}$; SANTIN, E. ${ }^{2}$ \\ 1 Empresa DaGranja \\ 2 Universidade Federal do Paraná
}

Endereço para correspondência: Elizabeth Santin: santin@ufpr.br

\begin{abstract}
In this trial fertile eggs from two different flocks of breeders (aged 30 and 60 weeks) from the same commercial line were incubated under commercial conditions. After hatching, birds were feathersexed and selected. Birds were allocated in four groups. Two of these groups were fed just after placement, while the other two were fed only after 12 hours of housed. Blood samples were collected weekly, starting at day one, and antibodies against Newcastle disease, Infectious Bronchitis and Infectious Bursal Disease virus were measured. The effect of these two variables on the local reaction after a subcutaneous injection with an oil vaccine adjuvant, and the presence and severity of macroscopic lesions in the digestive system organs, at 19 and 30 days of age were also evaluated. The 12 hours fasting period had affected negatively only the Newcastle disease virus antibodies titles at 7 days of age. Both variables had no effect on the severity of macroscopic lesions in the respiratory system and in the digestive system at 19 and 30 days old.
\end{abstract}

Key words: antibodies; immune response;Newcastle

\section{RESUMO}

Neste experimento ovos férteis oriundos de matrizes de uma mesma linhagem genética, mas com idades distintas (30 e 60 semanas), foram incubados sob condições rotineiras. Após a eclosão, as aves foram sexadas, selecionadas, e alocadas em quatro grupos. Dois destes grupos receberam ração logo após o alojamento, enquanto os outros grupos foram submetidos a jejum de 12 horas. Foram realizadas colheitas de sangue no momento do alojamento e semanalmente no decorrer do experimento. Os títulos de anticorpos para as doenças de Newcastle, Gumboro e Bronquite Infecciosa foram avaliados. Também foi avaliado o efeito destas duas variáveis sobre a resposta local à aplicação subcutânea de um veículo vacinal oleoso e sobre a presença e severidade de lesões macroscópicas nos órgãos do sistema digestório aos 19 e 30 dias de idade. Somente os títulos de anticorpos contra a doença de Newcastle, medidos aos sete dias, foram afetados pelo período de jejum de 12 horas. Nem o período de jejum nem a idade de matrizes afetaram a severidade das lesões macroscópicas no sistema respiratório e digestório aos 19 e 30 dias de idade.

Palavras-chave: anticorpos; Newcastle; resposta imune 


\section{INTRODUCTION}

The actual productive performance of broilers is the result of intense genetic selection applied to theirs predecessors, focused mainly in features related to dayold chick and meat production (for heavy breeders). This practice results in poultry with grate production potential - weight gain and feed conversion. However, these animals have been even less capable to respond appropriately to immunogenic stimuli (Dibner et al., 1998; Morgulis, 2002; Zekarias et al., 2002; Swaggerty et al, 2003a). It is known, for example, that commercial lineage of selected broilers for optimized productive performance has macrophages with less capability to phagocyte activity and oxidative metabolism (Zekarias et al., 2002; Swaggerty et al, 2003b).

Birds receive immunoglobulins produced by their mothers through the egg (maternal antibodies). These molecules are responsible for the preservation of their bodies against attacks (passive immunity) until they can produce their own defense (active immunity), which occurs from the first or second post-hatching week (Grindstaff et al., 2003; Groothuis et al., 2006; Maiorka et al., 2006). Among the factors that can affect physiological parameters and production of these animals are the breeders age (Vieira et al., 2005), their nutrition (Kidd, 2004), the quality of eggs related to time and conditions of storage (Wyatt et al., 1985), and the time between hatching and access to food and water (Peebles et al., 2004). Dibner et al. (1998) found that the contents of the yolk has no significant nutritional value for the chick in its first days of life, nevertheless it is an important source of nobler compounds, which will be used otherwise (phospholipids and immuno-globulins).

In the poultry industry, there is a lapse of time between the hatching and access of chicks to food and water. This time varies depending on the conditions and the production flow of each incubatory. The delay in access to nutrients and water can affect the metabolism of chicks in the early hours of life, leading to dehydration and ketosis (Maiorka, 2002; Peebles et al., 2004). Geyra et al. (2002) showed that a fasting of 48 hours may, in addition to delaying the development and weight gain of broilers, inhibit the genes expression responsible for differentiation and matura-tion of enterocytes in the post-embryonic period.

This research aimed to establish whether two ages of breeders (30 and 60 weeks) and two fasting periods (zero and 12 hours) could affect the immune response of chicks, measured by the dosage of immunoglobulins $G$ by the ELISA test.

\section{MATERIAL AND METHODS}

A thousand male one day-old broiler chickens of commercial lineage were used, 500 chicks were derived from 30 week-old breeders and the other 500 chicks were from 60 week-old breeders. Incubation was conducted according lineage management manual. All birds were vaccinated during the process of transferring the eggs from the incubator to the hatchery, done at 18 days of incubation using in ovo vaccine machine. The vaccination protocol included vaccines against Marek's (1.500 PFU's, HVT sample FC 126, serotype 3), Infectious Bursal Disease virus (Moulthrop G-603 strain) and avian pox virus (100 viral particles, chicken strain poxvirus). After 502 hours of hatching, the chicks were submitted to a process of selection, where birds with physical anomalies are discarded, sexed and then transported to the farm where they were weighted and housed. The time span between hatching, post-hatching processing (sexing, selection and transportation) and housing of the chicks in the experimental farm was of approximately 5 hours. The chicks from the younger breeders had an average weight of $40 \pm 0.5 \mathrm{~g}$ and those from 
Table 1 - Minimum feed composition used during all experimental period (kilogram of ingredient in each ton of feed)

\begin{tabular}{lcccc}
\hline \multicolumn{1}{c}{ Ingredient } & Pre-initial & Initial & Growth & Ending \\
\hline Corn & 539 & 566 & 652 & 686 \\
Integral soybean & 163 & 177 & 72 & 107 \\
Soybean Meal 45.5\% & 208 & 167 & 173 & 112 \\
Meat meal 40\% & 54.6 & 49 & 45 & 40 \\
Viscera flour & 20 & 20 & 13 & 11.3 \\
Feather / Blood meal & - & 5 & 17.5 & 17 \\
Chicken fat & - & - & 10.5 & 10 \\
Salt & 4 & 4 & 4 & 4 \\
Vitamin / Mineral premix & 4 & 4 & 4 & 4 \\
Alimet & 3.7 & 3.5 & 2.8 & 2.6 \\
Ajilys 64 & 1.9 & 2.3 & - & - \\
Lis-HCL-78 & - & - & 2.2 & 2.6 \\
Calcareous & 1.35 & 2.2 & 2.4 & 2.9 \\
C. de Colina 75\% & 0.7 & 0.7 & 0.7 & 0.7 \\
\hline
\end{tabular}

${ }^{1}$ By kilogram of feed supplies: Vit A: 8,300 Ul; Vit B1: 0.62mg; Vit B2: 2.35mg; Vit B6: 0.63mg; Vit B12: 1.32mg; Vit C: 16.7mg; Vit D3: 2,400Ul; Vit K: 1.5mg; Biotin: 0.15mg; Pantothenic acid: $9.32 \mathrm{mg}$; Niacin: 30.12mg; Folic acid: 1.42mg; Se: 0.65mg; I: 0.35mg; Fe: 57.72mg; Cu: 12.3mg; Mn: 17.4mg; Zn: 142mg; K: 7.9g; Mg: 0.90g; S: 0.73g.

the older breeders had an average weight of $48 \pm 0.8 \mathrm{~g}$.

The birds were housed in 20 experimental boxes "floor pen" of four square meters each $(2 \times 2 m)$, with a new pine shavings litter (not used before), which had been installed in a conventional commercial farm, curtainsided house, with no ventilation system. Each box had 50 chicks, a density of 12.5 birds $/ \mathrm{m}^{2}$ and one bell drinker and one pan feeder per box. Feeding was realized with a commercial chicken food (Table 1). The animals were distributed randomly in a factorial arrangement 2x2 (two breeder ages and two periods of fasting after hatching) in four treatments with five replicates (50 birds) each, being $\mathrm{T} 1$ chicks from 30-week-old breeder submitted to 5 hours of fasting after hatching; T2- chicks from 30 week-oldbreeder submitted to 12 hours of fasting after hatching; T3- chicks from 60 weekold-breeder submitted to 5 hours of fasting after hatching; T4- chicks from 60 week-old-breeder submitted to 12 hours of fasting after hatching. The time of 5 hours of fasting in T1 and T3 is due to a normal time need to transfer birds from hatchery to farm.

At $14^{\text {th }}$ day, the chicks were submitted to Infectious Bursal Disease virus (IBDV) vaccine (Moulthrop G-603 strain), by oral way (water), as a normal vaccine protocol adopted in the poultry farm where the trial was carried.

At $19^{\text {th }}$ and $30^{\text {th }}$ day, five birds (one bird per replicate) of each treatment were submitted to necropsy for macroscopic evaluation of coccidiosis intestinal lesions, according to Johnson and Reid (1970) lesion score model. Also at 30 days of age, the presence of macroscopic lesions of the organs of the digestive and cardio-respiratory system and Bursa of Fabricius (BF) were evaluated. When presented they were classified in mild, moderate or severe.

At 31 days of age an oil vaccine adjuvant was inoculated in ten chicks per treatment (two birds of each replicate). The inoculation was made subcutaneously in two different points (in the left tibiae-tarsus joint and in the medium third of left breast region). It was inoculated $0.5 \mathrm{ml}$ in each point. The adjuvant oil was chosen due to its capability of causing local reactions. The local injection was macroscopically evaluated five days after the inoculation with the use of a caliper to measure the visible lesions, always in its longitudinal way.

Blood samples from the right ulna vein were collected from the breeder flock to determine the titles (Geometric Medium TitleGMT) of $\lg G$ at different ages (30 and 60 
weeks). Furthermore, blood samples from 20 chicks per treatment (four birds per replicate) were collected on the days zero, seven, 21,28 and 35 to measure the antibodies against Infectious Bronchitis (IBV), Infectious Bursal Disease virus (IBDV) and Newcastle disease virus (NDV), using the ELISA Kit (Idexx®).

The statistical of vaccinal titles was done with the Tukey Test $(P<0.05)$ Statistix for Windows Copyright (C) 1985, 96 Analytical Software.

\section{RESULTS AND DISCUSSION}

The Table 2 shows the 30 and 60 weeks breeder flock antibody titles (IgG) that derived the chicks used in the trial. There were significant differences between IgG titles against Newcastle $(P=0.006)$ and Gumboro $(P=0.038)$ virus of 30 and 60 weeks breeders. No difference was observed in the Infectious Bronchitis titles $(P=0.070)$.

Younger breeder had lower IgG titles against NDV. This difference could be explained by the difference in the program of breeder vaccination as it was expected. The breeder antibody titles against the IBDV also showed difference that could be attributed to the vaccination program, which varies depending on the breeder age. However for IBV there was no difference between the titles of serum immunoglobulins of the two breeder flocks. In addition to the vaccination program for the two different groups of parents, by age, some characteristics of this type of virus can explain this behavior. The analysis of these issues, however, was not the objective of this study.

The Table 3 shows NDV, IBV, IBDV antibody titles ( $\operatorname{lgG}$ ) presented on the serum of day-old chicks (at the first housing day). There was no difference between the antibody titles against NDV and IBDV $(\mathrm{P}=0.632$ and $\mathrm{P}=0.369$, respectively). However, there was significant difference between IBV antibody titles in chicks descended of 30 and 60 weeks breeders $(P=0.000)$. The chick serology for NDV had no difference when the animals were grouped according to the age of their breeders.

Grindstaff et al. (2005) indicated that 10 to $20 \%$ of breeder $\lg$ average levels are transferred to the progeny through the yolk, however, this relationship was not found in this experiment. As for IBV, the experimental chicks derived from 30 weeks-old breeders showed higher levels of antibodies against the disease.

The Table 4 shows antibody titles (lgG) at seven days of age. Chicks derived from younger breeder presented higher titles for IBV when compared to older breeder derived chicks. The IgG titles against NDV were significantly lower to chicks with 12 hours post-hatching fast $(P=0.010)$ when compared to non fasting birds. There was neither difference between NDV and IBDV titles of different breeder ages groups nor between IBV and IBDV titles of the two fasting period groups.

Serology for IB of experimental birds at seven days of age showed the same tendency found at the housing day. There was difference between groups of birds derived from breeders of different ages, and chicks from younger breeder had the highest titles. The decreasing of titles of the zero to seven days of both groups remained the

Table 2 - Antibody serum titles ( $\lg G$ ) of broiler breeders that originated the chicks used in the experiment (GMT).

\begin{tabular}{cccc}
\hline Breeder Age & ND & IB & IBD \\
\hline 30 weeks & $4459 \pm 565^{\mathrm{a}}$ & $5567 \pm 3674$ & $4717 \pm 3633^{\mathrm{a}}$ \\
60 weeks & $7596 \pm 3630^{\mathrm{b}}$ & $3789 \pm 1676$ & $6759 \pm 1707^{\mathrm{b}}$ \\
$P$ - value & 0.0066 & 0.0704 & 0.0380 \\
\hline
\end{tabular}

ND - Newcastle Disease; IB - Infectious Bronchitis; IBD - Infectious Bursal Disease.

${ }^{a-b}$ Different letters in the same column indicate significant difference $(P<0.05)$. 
Table 3 - Chicks antibody serum titles (IgG) at the first housing day (GMT)

\begin{tabular}{cccc}
\hline Breeder Age & ND & IB & IBD \\
\hline 30 weeks & $6101 \pm 3562$ & $6457 \pm 3702^{\mathrm{a}}$ & $5781 \pm 1588$ \\
60 weeks & $6617 \pm 2795$ & $2745 \pm 1452^{\mathrm{b}}$ & $5356 \pm 1195$ \\
$P$-value & 0.6320 & 0.0004 & 0.3698 \\
\hline
\end{tabular}

ND - Newcastle Disease; IB - Infectious Bronchitis; IBD - Infectious Bursal Disease.

${ }^{a-b}$ Different letters in the same column indicate significant difference $(P<0.05)$.

Table 4 - Chicks antibody serum titles (IgG) at the seventh day of age (GMT)

\begin{tabular}{cccc}
\hline Breeder Age $(\mathrm{A})$ & $\mathrm{ND}$ & $\mathrm{IB}$ & $\mathrm{IBD}$ \\
\hline 30 weeks & $1629 \pm 1052$ & $1969 \pm 1582^{\mathrm{a}}$ & $2879 \pm 1055$ \\
60 weeks & $1860 \pm 1270$ & $691 \pm 926^{\mathrm{b}}$ & $3145 \pm 1275$ \\
$P$-value & 0.3825 & 0.0001 & 0.3457 \\
\hline Fasting $(\mathrm{B})$ & $\mathrm{ND}$ & $\mathrm{IB}$ & $\mathrm{BD}$ \\
\hline Yes & $1397 \pm 710^{\mathrm{a}}$ & $1149 \pm 1580$ & $3018 \pm 976$ \\
No & $2092 \pm 1411^{\mathrm{b}}$ & $1511 \pm 1270$ & $3006 \pm 1350$ \\
$P$-value & 0.0101 & 0.2393 & 0.9648 \\
\hline A x B & & & \\
\hline$P$-value & 0.2142 & 0.3617 & 0.6327
\end{tabular}

ND - Newcastle Disease; IB - Infectious Bronchitis; IBD - Infectious Bursal Disease.

${ }^{a-b}$ Different letters in the same column indicate significant difference $(P<0.05)$.

same proportion (between $65 \%$ and $70 \%$ ), suggesting that the treatments had no influence in this depletion.

Apparently, the fasting period of 12 hours post-hatching was able to significantly reduce the levels of immunoglobulin $G$ ( $\lg G$ ) against the Newcastle virus at seven days of age, suggesting that the absorption of these molecules has been affected by lack of food in the early hours of chicks' life. This observation matches to what was stated by Dibner et al. (1998), who claim that in the absence of exogenous food, the newly hatched chicks can make use of the contents of the yolk to obtain energy, rather than use these molecules such as antibodies or cellular components. Although the fasting has caused a reduction in titles of immunoglobulins against NDV, this effect was not observed in the levels of antibodies against IBDV and IBV.

At 21 days of age there were no significant differences between the titles of antibodies against NDV or IBDV, neither between the ages of two breeder groups, nor between the groups submitted or not to fasting after housing. The wide range of titles in this sample (illustrated by the standard deviation in each treatment) may have contributed to the lack of significance on the results. In relation to NDV vaccine it also should be considered that the evidence of maternal antibodies tends to disappear around the third week of age (Grindstaff et al., 2005). When there is no environmental challenge, these titles should not be detectable until the age of slaughter. The same should happen with the titles of maternal antibodies to IBDV. As a vaccination at 14 days old was done, the titles observed after that date probably refer to the active immunity, which is developed by the bird in response to the vaccine challenge.

The antibody titles against Infection bursal disease remained stable from 21 to 28 days, so it was not possible to observe statistical difference between treatments. At this age, the titles found were referred already to the active immunity, since the birds were challenged by the vaccination at 14 days old, with the use of live vaccine administered by drinking water. At this age, it was not possible to detect antibodies against NDV and IBV, showing total collapse of maternal titles (passive immunity), which suggests lack of environmental challenge (field virus). 
Table 5 - Macroscopic lesions measures after oil vaccine adjuvant inoculation (centimeters)

\begin{tabular}{ccc}
\hline Breeder Age (A) & Foot lesion & Breast lesion \\
\hline 30 weeks & $1.953 \pm 0.343^{\mathrm{a}}$ & $2.457 \pm 0.402$ \\
60 weeks & $2.184 \pm 0.403^{\mathrm{b}}$ & $2.085 \pm 0.873$ \\
$P$-value & 0.0389 & 0.0556 \\
\hline Fasting (B) & Foot lesion & Breast lesion \\
\hline Yes & $2.095 \pm 0.348$ & $2.188 \pm 0.841$ \\
No & $2.042 \pm 0.430$ & $2.354 \pm 0.484$ \\
$P$-value & 0.6263 & 0.3853 \\
\hline A x B & & \\
\hline$P$-value & 0.2804 & 0.0630 \\
\hline${ }^{\text {a-b }}$ Different letters in the same column indicate significant difference $(P<0.05)$.
\end{tabular}

At 35 days of age, the antibody titles against IBDV were higher compared to samples of 28 days for all treatments. Even though, there was no significant difference between them. In the sixth week of age the antibody titles against IBDV have remained close to those found in previous samples, not being possible to identify differences between treatments.

The macroscopic evaluations carried at 19 and 31 days old, which aimed to assess the incidence of injuries consistent with eimeriosis, did not reveal any kind of trend considering the treatments. Ding et al. (2004) concluded that it is possible to control this disease using maternal vaccines. Those authors claimed that the antibody transfer from mother to their progeny may be able to provide protection against clinic coccidiosis, reducing the incidence of macroscopic lesions and other clinical manifestations of this disease. The macroscopic analysis for the incidence of other types of injures to the digestive system also did not reveal any kind of influence of the treatments. Likewise, there was no kind of trend in the presence or absence of macroscopic lesions in the respiratory tract of birds submitted for necropsy on those dates.

The Table 5 shows the data of the macroscopic lesions measures (in centimeters) caused by the subcutaneous injection of oil vaccine adjuvant in two different points. There was only significant difference $(P=0.038)$ between chicks derived from 30 and 60 weeks breeders on the measures of foot lesions, being the younger group with milder macroscopic lesions.

Although there was a significant difference in the size of the foot injury caused by subcutaneous injection of an oil adjuvant between groups of chicks produced by 30 and 60 weeks breeders, it was not possible to determine the exact cause of this amendment. Chicks born of bigger eggs have more reserves, which would allow them to develop themselves more quickly and have greater capability to develop active immune response, either non-specific or cellular. However, measurements of the breast injury showed no difference between treatments. Cheema et al. (2003) said that although the modern broilers lines have less capacity of humoral immune response when compared with strains of the past, they present greater capacity for local response or mediated by cells.

The fasting period used in this experiment (12 hours post-hatching) may have affected the way that the influences occurred on each parameter considered. Maiorka et al. (2006) cited that the negative effects of fasting on birds are more intense when they involve food and water restriction. Dibner et al. (1998) claimed that it is a common practice in some commercial incubatory a 24 hours fasting after hatching. In theirs study, 72 hours of food and water restriction were used. Geyra et al. (2002) worked with a 48 hours fasting period. Wyatt et al. (1985) submitted the birds to a fasting for up to 32 hours. These time variations between the fasting also cause problems in the 
comparison of results between these different studies.

\section{CONCLUSIONS}

The 12 hours post-hatching fasting period adversely affects the levels of maternal immunoglobulins $G$ against NDV at seven-days-old broilers, but it does not affect the maternal antibodies against IBDV and IBV.

The breeder age and post-hatching fasting period neither have an effect on the incidence and/or severity of macroscopic lesions in the respiratory system, nor on those related to coccidiosis and enteritis in the digestive system at 19 and 31 days old. Further analyses may be necessary, with the use of longer post-hatching fasting periods, to make the effects observed in this study more evident.

\section{REFERENCES}

CHEEMA, M.A.; QURESHI, M.A.; HAVENSTEIN, G.B. A comparison of the immune response of a 2001 commercial broiler with a 1957 randombred broiler strain when fed representative 1957 and 2001 broiler diets. Poultry Science, v.82, p.15191529, 2003.

DIBNER, J.J.; KNIGHT, C.D.; KITCHEL, M.L. et al. Early feeding and development of the immune system in neonatal poultry. Journal of Applied Poultry Research, v.7, p.425-436, 1998.

DING, X.; LILLEHOJ, H.S.; QUIROZ, M.A. et al. Protective immunity against Eimeria acervulina following in ovo immunization with a recombinant subunit vaccine and cytokine genes. Infection and Immunity, v.72, n.12, p.6939-6944, 2004.

GEYRA, A.; UNI, Z.; GAL-GARBER, O. et al. Starving affects CDX gene expression during small intestinal development in the chick. Journal of Nutrition, v.132, p.911-917, 2002.

GRINDSTAFF, J.L.; BRODIE, E.D.; KETTERSON, E.D. Immune function across generations: integrating mechanism and evolutionary process in maternal antibody transmission. Proceedings of the Royal Society of London Series B - Biology Sciences, v.270, p.2309-2319, 2003.
GRINDSTAFF, J.L.; DEMAS, G.E.; KETTERSON, E.D. Diet quality affects egg size and number but does not reduce maternal antibody transmission in Japanese quail Coturnix japonica. Journal of Animal Ecology, v.74, p.1051-1058, 2005.

GROOTHUIS, T.G.G.; EISING, C.M.; BLOUNT, J.D. et al. Multiple pathways of maternal effects in blackheaded gull eggs: constraint and adaptive compensatory adjustment. Journal of Evolutionary Biology, v.19, n.4, p.1304-1310, 2006.

JOHNSON, J.; REID, W. Anticoccidial drugs: Lesion scoring techniques in battery and floor-pen experiments with chickens. Experimental Parasitology, v.28, p.30-36, 1970.

KIDD, M.T. Nutritional modulation of immune function in broilers. Poultry Science, v.83, p.650-657, 2004.

MAIORKA, A. Efeitos da idade da matriz, do jejum, da energia da ração e da glutamina sobre o desenvolvimento intestinal e atividade enzimática do pâncreas de pintos de corte. 2002. 103p. Tese (Doutorado). Universidade Estadual Paulista, Faculdade de Ciencias Agrarias e Veterinárias, Jaboticabal.

MAIORKA, A.; DAHLKE, F.; MORGULIS, M.S.F.A. Adaptações pós-eclosão em frangos. Ciência Rural, v.36, n.2, p.701-708, 2006.

MORGULIS, M.S. 2002. Imunologia aplicada. In: MACARI, M. (Ed.) Fisiologia aviária aplicada a frangos de corte. Jaboticabal: Funep, 2002. p.231245.

PEEBLES, D.E.; KEIRS, R.W.; BENNETT, L.W. et al. Relationship among post-hatch physiological parameters in broiler chicks hatched from young breeder hens and subjected to delayed brooding placement. International Journal of Poultry Science, v.3, n.9, p.578-585, 2004.

PS MANAGEMENT MANUAL ROSS $308^{\circledR}$. Disponível em: <http://www.avigen.com/ output.aspx>. Acesso em: 23 abr. 2008.

SWAGGERTY, C.L.; PEVZNER, I.Y.; FERRO, P.J. et al. Association between in vitro heterophil function and the feathering gene in commercial broiler chickens. Avian Pathology, v.32, n.5, p.483-488, 2003a.

SWAGGERTY, C.L.; PEVZNER, I.Y.; LOWRY, V.K. et al. Functional comparison of heterophils isolated from commercial broiler chickens. Avian Pathology, v.32, n.1, p.95-100, 2003b.

VIEIRA, S.L.; ALMEIDA, J.G.; LIMA, A.R. et al. Hatching distribution of eggs varying in weight and breeder age. Brazilian Journal of Poultry Science, v.7, n.2, p.73-78, 2005. 
WYATT, C.L.; WEAVER Jr., W.D.; BEANE, W.L. Influence of egg size, eggshell quality and posthatch holding time on broiler performance. Poultry Science, v.64, p.2049-2055, 1985.
ZEKARIAS, B., TER HUURNE, A.A.H.M.; LANDMAN, W.J.M. et al. Immunological basis of difference in disease resistance in the chicken. Veterinary Research, v.33, p.109-125, 2002. 